\title{
CHINA AND THE FUTURE OF AFRICA CONTINENTAL FREE TRADE AREA (ACFTR): CHALLENGES AND OPPORTUNITIES
}

\author{
Sheriff Ghali Ibrahim ${ }^{1}$, Ahmet Arabaci ${ }^{2}$ and Sheriff Aminu Ibrahim ${ }^{3}$ \\ ${ }^{1}$ Department of Political Science and International Relations, University of Abuja \\ ${ }^{2}$ Department of Political Science and International Relations, Nile University of Nigeria \\ ${ }^{3}$ Department of Education and Social Welfare, Abuja Municipal Area Council
}

Email: sherfboy@yahoo.com; Phone: +234-7063372013

Cite this article:

Sheriff G.I., Ahmet A., Sheriff A.I. (2021), China and the Future of Africa Continental Free Trade Area (ACFTR): Challenges and Opportunities. African Journal of Economics and Sustainable Development 4(3), 156-169. DOI:

10.52589/AJESDOVPKTDUY.

\section{Manuscript History}

Received: 3 Sept 2021

Accepted: 28 Sept 2021

Published: 12 Oct 2021

Copyright (c) 2020 The Author(s). This is an Open Access article distributed under the terms of Creative Commons AttributionNonCommercial-NoDerivatives 4.0 International (CC BY-NC-ND 4.0 ), which permits anyone to share, use, reproduce and redistribute in any medium, provided the original author and source are credited.
ABSTRACT: The paper examines the nexus between China's coupling and economic relations with Africa under the Africa Continental Free Trade Area (ACFTA). It also analyses the future of ACFTR especially with the technical support African states will be enjoying through their collaboration with China or in the absence of such support, how Africa may utilize the opportunities available and the likely challenges to encounter in the implementation of ACFTA. Using the secondary source of data, findings show that the implementation of ACFTA can lead to substantial higher bilateral trade between China and Africa. The paper concludes that both in the short and long run, China and African countries stand to benefit immensely in the implementation of ACFTA. The paper recommends that African countries should ratify and domesticate ACFTA and should collaborate with China for the purpose of harnessing the opportunities and surmounting the likely challenges that may emanate from the implementation process.

KEYWORDS: Trade; Free Trade; Free Trade Area; Africa Continental Free Trade; Challenges; Opportunities 


\section{INTRODUCTION}

It is without a doubt that Africa is rich in both human and material resources which can be galvanized in achieving development through effective utilization of these resources. It is obvious that each and every country in Africa have potentials for economic growth, development and modernization which may produce well for the African people and serve international markets for better and greater returns. The fundamental issue with African economies starting from the eastern region, western, southern and central regions is that the industrial revolution has not yet taken place. African societies have remained agrarian and hinged on primary production without technical knowledge of sophisticating the production process to be able to compete in the international market.

The industrial process and development of Africa have been weakened by the colonial experience of Africa and when Africa became decolonized, other worlds had already taken off and left the continent to exclusively rely on what was produced or manufactured in Europe and America. When the African local industries started reemerging and trying to occupy a significant place in the global production arena, it was a bit late for African products to compete with the European and American-made products and thereby making African products not fit in the international market. What remains of Africa is to continue to provide raw materials for the European and American industrial consumption with the hope that these finished products would return to Africans for consumption. This trend is not healthy for the growth and development of an economy.

The second variable is that African countries have not been trading among themselves as they do not produce what is required at the African markets, which are predominantly finished goods. What Africa trade for are ultimate sources of energy such as oil and gas, and other related items needed for consumption. There are some regional and sub-regional organizations that try to promote trade within such regions, but there are intervening variables that affect such trade systems. For instance, the ECOWAS protocol on the free movement of goods, labour and capital subjects itself to some glitches, where some people are not allowed entry and extortion by either customs or immigration officials is imminent. The objective of this research, therefore, is to provide answers to the following questions: to what extent can China significantly influence the implementation of ACFTA? How could ACFTA lead to substantial higher bilateral trade between China and African countries? What are the significant opportunities available to China and African countries during and after the full implementation of ACFTA? What are the likely challenges to be encountered in exploring the relationship between China and Africa with regard to ACFTA?

\section{Material and Method}

The methodology used in this research is the library descriptive research from the secondary source of data where materials were derived from journal articles, newspapers, periodicals and reports. The material and method are also supported by commercial liberalist theory as the theoretical framework to support the research. 


\section{LITERATURE REVIEW}

Conceptual Review: Trade literally can be defined as such process or activities that involve the transfer of goods and services from an individual or group to another person or persons in exchange for a recognized and adopted exchange medium. In the work of Hayes (2021), it is an activity or exercise that involves the buying and selling of goods and services, or the exchange of goods or services between parties with compensation paid by a buyer to a seller. It is the exercise where goods and or services are exchanged willingly from an original possessor who is the seller to a buyer who possesses or benefits from the service through a medium of exchange agreed upon by both parties. As a business activity, the medium of exchange for the transfer of goods or service ownership is central to trading exercise as argued in the writings of Surbhi (2018). Surbhi explains why even during the barter stage of trading, the transfer of goods or service ownership was anchored on the exchange for other goods or services as agreed by parties involved, as the medium of exchange.

The importance of trade is hinged on the division of labour in the production process either domestically, or at the international scene commonly referred to as the comparative advantage of states as argued in the works of Kraay and Dollar (2004) that trade exists due to production specialization and or division of labour. The specialization or division mostly natural, though artificial in some instances, is a prominent economic activity where individuals, groups or states concentrate on the production of what they have a comparative advantage of either perceived or real and in the quest for other products or services, trade their output.

Free trade is an international trade theory that favours commercial and trading activities between nation-states with less or no restriction. It calls for the liberalization of international trade where the market forces especially the "demand and supply" are the major determinants of prices among others. Longley (2018), in his work, describes free trade as a theory or practice which promotes international commercial or trading competitions. Paul (2013) also agrees in his work that it is an international trade policy that is built on the free market idea, which provides for an import and export regime that is free from all forms of government restrictions and interventions. As against the protectionist opinion, free trade is a policy under which national governments eliminates all form of tariffs, taxes or duties on import and export activities.

Central to the idea is the assumption that supply and demand factors, operating on a global scale, will ensure that production happens efficiently. The theory according to Kent (2004) assumes that nation-states in the international market have similar levels of economic power and the differences among them have to do with accidents of nature and differences in taste. Hence, the government has nothing to do other than to protect or promote trade and growth because market forces will do so automatically. Silvana, Koren and Milan (2019), have in their work, identified features that characterize a free trading exercise to include the trade of goods and in services without taxes such as tariffs and other barriers like subsides, absence of tradedistorting policies that provide a domestic advantage as well as free trade agreements that promote and improve export and import activities.

As popularly associated with modern liberalism, most arguments of the free trade theory found their base on Ricardo's comparative advantage theory. Franklin (2000) noted that as assumed by the comparative advantage argument, free trade is a source of a higher level of output and income as it enables large scale production of advantageous goods and consumption of easily 
imported ones. In the writings of Gregory (2015), the removal of import restriction presents the consumer with lower prices of goods while reducing government spending by the absence of subsidies, as well as increasing foreign investment and the encouragement of technological transfer.

In the argument of Sheriff, Bibi and Abdulkarim (2021), the Africa Continental Free Trade Area will be the largest in the world in terms of the market if fully harnessed especially with the plans and programs across Africa sub-regions.

The plan is to connect eastern Africa with central Africa with the projects in Angola, Zambia, Mozambique, Liberia, Ghana etc which are great signs that the AFCFTR is being backed by a solid foundation in its inception with the strong hope that as it is the largest free trade area in the world it would serve as a driver to Africa's growth and development (Sheriff, Bibi and Abdulkarim, 2021).

Free Trade Area: A free trade Area is simply a geographical region made up of member countries that sign a trade agreement that binds them together in terms of economic cooperation. The free trade area as conceived by World Trade Organization (WTO, 1994) in its General Agreement on Tariff and Trade (GATT) covered only the agreement of trading in goods while article V of General Agreement on Trade and Services (GATS) as the name implies, covered every economic agreement. The "Free Trade Area" practice is a form of economic integration that provides for unrestricted or less restricted trading and commercial activities among member states. Rasure (2020), in his writings, believes that Free Trade Area is a facilitator of international trade as well as the gains of trading along the lines of comparative advantage through an international division of labour and specialization. In his argument, we could understand that a free trade area is a region whose member states have mutually consented to the elimination or at least the limitation of trade barriers in the form of tariffs or quotas among themselves by signing a free trade agreement.

The major goal around the free trade area and agreements is the elimination of trading barriers. The Corporate Finance Institution (2015) recorded that the main goal of the free trade area is to bring down barriers in trading, with specifications on tariffs and import quotas to encourage free trading of goods and services between member states. Hence, vital to the free trade agreement is the submission by member countries to establish a common set of policies that regulates trade terms, tariffs and quotas especially as it relates to them. While as written by Anne (1995), in differentiating free trade and customs union, the member-states reserve the right to independent tariff and quota policies towards non-member-countries usually referred to as the third party.

\section{Theoretical Review}

Mercantilism: There is a great contribution in the theoretical journeys of free trade and one major argument that is salient is the fact that "most European economists" that reigned "between 1500 and 1750" have been identified as mercantilists, believing in free trade among nations, individuals and states (Heckscher, 1935). This is to argue that mercantilism is a classical theory that delves into the thematic issues of free trade. In the works of Magnusson (2003), Thomas Mun reigned between 1571 and 1641 and was the pioneer of the mercantilist movement. Another major contributor to mercantilist literature was James Steuart in his work "principles of political economy" which was published in 1767. James has itemized some of 
the salient principles of mercantilism especially as it deals with the concept of free trade (Magnusson, 2003). Some of these principles have to do with more exports and fewer imports which are used as strategies of economic improvement.

Italy's Giovanni Botero (1544-1617), Antonio Serra (1580), French Jean Bodin and sir Colbert have been great mercantilists of their times, believing in free trade and allowing countries to export more than they import in international trade (Magnusson, 2003). Mercantilism was also developed in the works of an Austrian lawyer Philipp Wilhelm von Hornick, who established in his work "Austria Over All, If She Only Will" in 1684, which embodies the following principles (Ekelund and Hebert, 1975): (1) that every little bit of a country's soil be utilized for agriculture, mining or manufacturing (2) that all raw materials found in a country be used in domestic manufacture, since finished goods have a higher value than raw materials (3) that a large, working population be encouraged (4) that all exports of gold and silver be prohibited and all domestic money be kept in circulation (5) that all imports of foreign goods be discouraged as much as possible (6) that where certain imports are indispensable they be obtained at first hand, in exchange for other domestic goods instead of gold and silver (7) That as much as possible, imports be confined to raw materials that can be finished (8) that opportunities be constantly sought for selling a country's surplus manufactures to foreigners, so far as necessary, for gold and silver (9) that no importation be allowed if such goods are sufficiently and suitably supplied at home.

From the classical theoretical movement, Adam Smith has been in line with the ideas of scholars like Robert E. Ekelund and Robert D. Tollison, to call mercantilism "a rentseeking society". The above scholars especially Smith, see Mercantilism as an "enormous conspiracy by manufacturers against consumers" where manufacturers should always produce and the consumers are not motivated to produce but only buy (Ekelund and Hebert, 1975).

Comparative advantage: The comparative advantage theory is a theory of free trade that explains how a country produces more and consumes less of goods and services upon which they possess comparative advantage (O'Sullivan, and Sheffrin,2003). The emphasis on comparative advantage is primarily hinged on the ability of a country to produce a unit of goods at a lower relative cost compared with other(s) countries. David Ricardo has been one of the most popular proponents of the comparative advantage theory in his classical discourses (Maneschi, 1998).

\section{Empirical Review}

Africa Continental Free Trade Area (AfCFTA) came into existence with the signing of the Kigali Treaty Agreement in Rwanda in March 2018 (ITC, 2018). The trade agreement was first signed by forty-four (44) member-states of the African Union (AU). Currently, AfCFTA has fifty-four members though just half that number has ratified the agreement (Onwuka \& Ozegbe, 2020). AfCFTA was established with the objectives to create a single liberalized market for goods and services, facilitate movement of people in order to deepen the economic integration of the African continent and eliminate tariff and non-tariff barriers on all trade. The International Trade Center (ITC) in identifying key objectives of establishing AfCFTA outlined the creation of Economic Communities (EC) which will, in turn, promote economic, social and cultural development and integrate the African economies; provide a framework for the development, mobilization and utilization of human and material resources; promote cooperation in all fields of human endeavour, raise the human living standard and harmonize 
policies among existing and future economic communities (ITC,2018). These objectives will aid in the actualization of the African Union (AU) Agenda 2063 "the Africa we want" (Onwuka \& Ozegbe, 2020).

For the trade agreement to be well implemented, there is the very need for integration within the African continent which the first step would be the creation of Regional Economic Communities (REC) and Free Trade Areas (FTA) that would serve as building blocks towards the actualization of the Africa Continental Free Trade Area (AfCFTA). In the writings of Lukman (2020), to achieve the objectives of trade promotion, the Africa Continental Free Trade Area (AfCFTA) has created different Free Trade Agreements across sectors such as petrochemical industries, textile industries, and maritime industries among others. The Regional Economic Communities recognized by African Union are the Arab Maghreb Union (AMU), the Community of Sahel-Saharan States (CEN-SAD), the Common Market for Eastern Southern Africa (COMESA), the East African Community (EAC), the Economic Community of Central African States (ECCAS), the Economic Community of West African States (ECOWAS), the Intergovernmental Authority on Development (IGAD) and the Southern African Development Community (SADC) (ITC, 2018).

It is through this integration and creation of Regional Economic Communities that African nations will have the opportunity to move and trade freely amongst themselves and increase the Gross Domestic Product (GDP) of the continent which will directly bring about development and reduce the poverty rate in the continent. This assertion is in line with the argument of Onwuka \& Ozegbe (2020) who argued that the AfCFTA agreement if properly implemented will unite approximately 1.3 billion people, create a $\$ 3.4$ trillion economic bloc and usher in a new era of development in Africa. This position is also upheld by Patience (2020) who in her dictum saw regional integration to be an engine of accelerating regional economic growth, intra-regional trade, reducing poverty, bringing about regional prosperity and expanding access to global markets. Patience further argued that AfCFTA is an ongoing effort to foster economic growth and reduce poverty within the African continent.

The Africa Continental Free Area (AfCFTA) is the largest trade agreement after the World Trade Organization and it has been set to create access to over USD 3 trillion markets which will further boost intra-African trade by 52 percent in four years (Witschge, 2018). The intraAfrican trade boost will be achieved gradually with trade used more effectively as an engine of growth and sustainable development. It is expected that at the first phase of AfCFTA implementation, intra-African trade will double by the year 2022 and by extension, Africa would have a common voice in global trade negotiations (Lukman, 2020). In an intellectual work, Melo \& Tsikata (2013) opined that despite efforts to promote regional integration and Regional Economic Communities (REC), several mitigating factors ranging from external economic shocks and high growth volatility have been met with. These mitigating factors or obstacles have been categorized in the study of ITC (2018) to be structural and institutional in nature.

A fundamental obstacle under the structural obstacle is the challenge of infrastructure deficit which has posed a major obstacle to the idea of the AfCFTA trade agreement and its implementation across the continent. Knowing this challenge, Sheriff, Farouk and Abdulkareem (2021), tried proffering a solution when they carried out a study on the African Continental Free Trade Area (AfCFTA) and the One Belt, One Road initiative (OBOR) of China. They also posit that Africa and Asia which share many similarities are two continents 
that can work hand in hand to achieve trade and infrastructural development. China looks to expand its trade routes by connecting the world by road through its Belt and Road Initiative (BRI) which is targeted to be completed come the year 2045 (Sheriff, Farouk \& Abdulkareem, 2021). The Belt and Road Initiative in the argument of Sheriff, Farouk \& Abdulkareem (2021) will provide Africa with infrastructure and investment opportunities which will provide Africans with assistance in its implementation of the AfCFTA trade agreement. They further argued that BRI will provide an avenue for Africans to move their merchandise across borders with much ease, assist Africa in being industrialized and have the ability to trade not only in primary goods but in processed commodities.

The intra-African trade will be promoted through the elimination of tariff and non-tariff barriers, enhanced custom procedure and enhanced cooperation that will bring about regional and continental value chain, enhanced socioeconomic development, diversification and industrialization across Africa. For these reasons, African governments participate in RECs which will make small markets attractive to both local and foreign markets (ITC, 2018).

\section{Theoretical Framework}

Commercial liberalism is a theory of international relations developed in the works of John Baylis and Steve Smith in 2006, which holds the argument that cooperation, commerce and interdependence of states on commercial activities and free trade will not only discourage states from going to war but will ensure peace and security among them (John and Steve, 2006). This theory is a guiding principle of the western world as they develop the capitalist world by preaching and pontifying trade liberalization and freedom to do so. The theory explains the topic under study by the need between and among African states to trade among themselves under the auspices of AFCTA. It can be argued from this theory that inter-coupling between Africa and China in order to achieve a greater level of economic and trade interaction among African states is not only feasible but an instrument of a formidable alliance between Africa and China.

\section{FINDINGS AND DISCUSSION}

International economic relations and trade among African states depend on the nature of resources each state has and how it is able to modify such resources for further consumption, while China-Africa relations under the Africa continental free trade area would be how china can help each African country to discover or rediscover its potentials especially in the partnership each country would sign or has already signed in developing such resources through an industrial process.

The major challenge that may affect AFCFTA is the overdependence of African states on raw materials and their inability to industrialize or to find a common ground upon which such resources can be adequately harnessed in order to channel their wealth of nations into the proper channel for development. The second challenge is that if the AFCFTA is not fully supported by African industrialization to start manufacturing of goods from the quantum of the resources they have, the advanced economies of the world will take advantage of that even if there is no proper arrangement on that. The forum on China-Africa cooperation is a convincing forum through which Africa can truly achieve industrialization and development due to mutual trust and capacity building of Africa by China in all ramifications. Figure one below shows how 
African countries depend on natural resources which suggest the indispensability of partnering with China to harness such resources for greater market and development.

a. Resource-rich regions

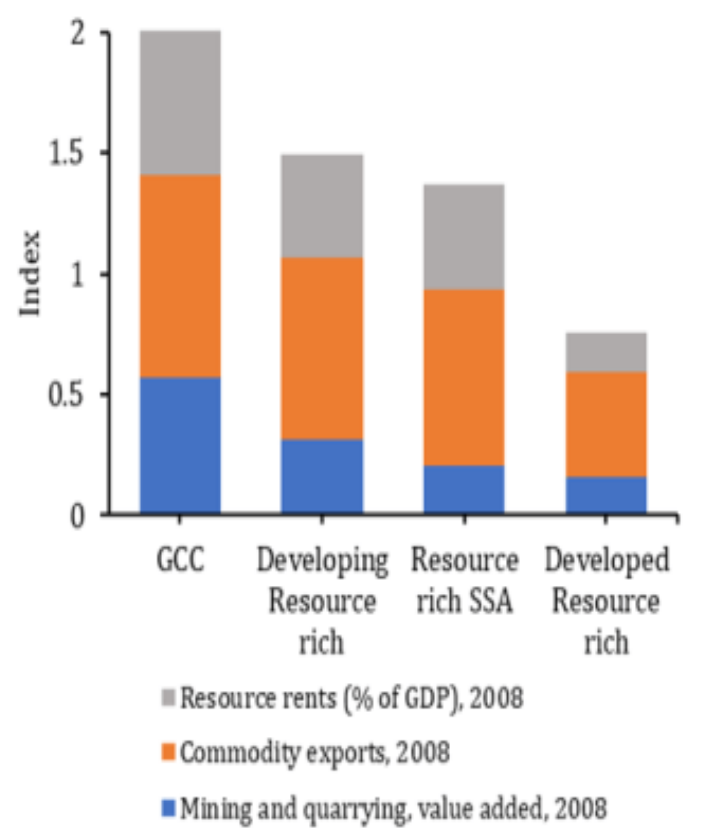

b. SSA Resource-rich

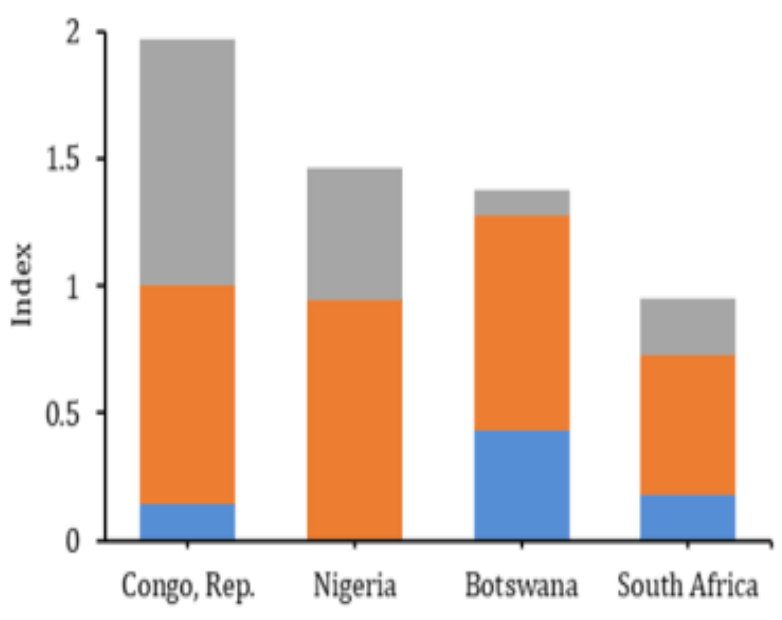

= Resource rents (\% of GDP), 2008

n Commodity exports, 2008

= Mining and quarrying, value added, 2008

Source: United Nations National Account Statistics, UN Comtrade and WDI.

Fig. 1.1: Dependence on natural resources, regions and sub-Saharan Africa, 2008, Index

The above figure shows that the resource-rich countries of sub-Saharan Africa are Congo, Nigeria, Botswana and South Africa, which also portend that in case of the maturation of AFCFTA, the above-mentioned states hold an advantageous position to gain especially with their ability to integrate with China in co-industrial production.

It is pertinent to mention that each and every country in Africa is unique in terms of natural resource endowment. Most of the major areas where those countries endowed with such resources will enjoy significantly in the AFCFTA arrangement with the inclusion of China are those with natural gas, oil, gold, metal and minerals, coal, land and protected areas. The majority of African countries will benefit from mechanized agriculture as about $90 \%$ of African countries are rich in fertile land especially the resource-poor Sub-Sahara Africa states. This can be seen in figure 2 below: 


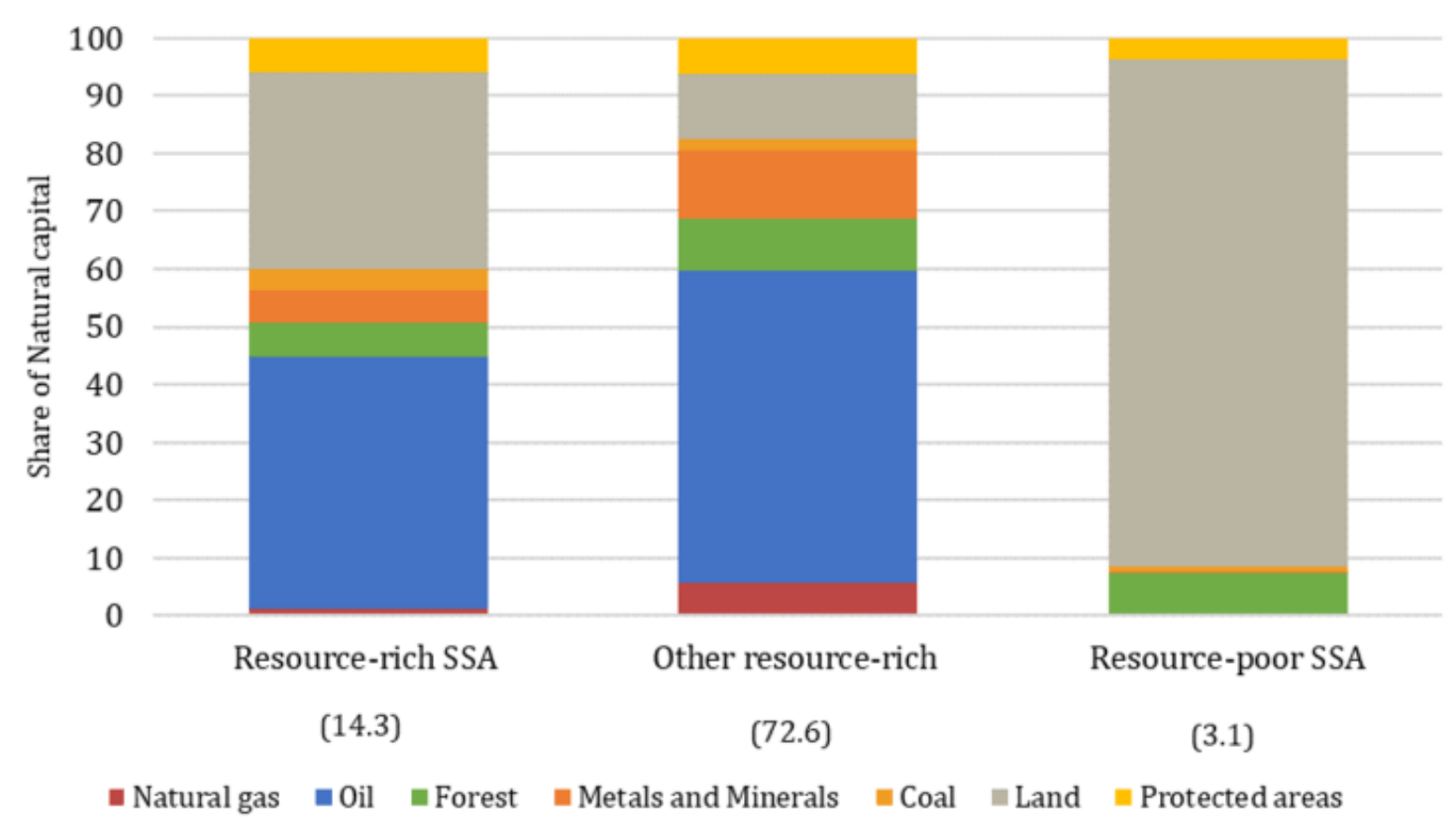

Source: The Changing Wealth of Nations (2018) dataset, World Bank Note: The numbers in parentheses are weighted average natural capital per capita expressed in 2014 US\$ thousands

Fig.2: Components of natural wealth in resource-rich sub-Saharan Africa, 2014

It can be observed from the above figure that $14.3 \%$ of countries in Sub-Sahara Africa are very resource-rich, $72.6 \%$ of these countries are fairly resource-rich while $3.1 \%$ of the countries are resource-poor. Apart from agriculture, China can help in the mining process of metals and minerals that are significantly needed for use in Africa but under-explored. If well explored, these countries will boost their markets and earn more national income. On the basis of comparative advantage, African countries that are oil-rich can collaborate with China in refinery rehabilitation, reconstruction and building new ones for effective and sufficient refining of crude oil for more income to be generated. Nigeria for example, Angola and Sudan among others can capitalize on this aspect. Nigeria is blessed with oil but still imports oil from outside due to dilapidated refineries that are not able to refine the oil.

Another factor that gives China leverage over other countries in the world in partnering with Africa to execute the successes of the AFCFTA is that China, since 2015, has been the largest country in the world in terms of manufacturing output both at the national and international level. This can be seen in table1 below: 
African Journal of Economics and Sustainable Development

ISSN: 2689-5080

Volume 4, Issue 3, 2021 (pp. 156-169)

www.abjournals.org

Table 1: Leading countries on manufacturing output, 2015

\begin{tabular}{|c|c|c|c|}
\hline Country & $\begin{array}{l}\text { Manufacturing Output } \\
\text { (USD in billions) }\end{array}$ & $\begin{array}{l}\text { Percent of } \\
\text { National Output }\end{array}$ & $\begin{array}{l}\text { Percent of Global } \\
\text { Manufacturing }\end{array}$ \\
\hline China & $\$ 2,010$ & $27 \%$ & $20 \%$ \\
\hline United States & 1,867 & 12 & 18 \\
\hline Japan & 1,063 & 19 & 10 \\
\hline Germany & 700 & 23 & 7 \\
\hline South Korea & 372 & 29 & 4 \\
\hline India & 298 & 16 & 3 \\
\hline France & 274 & 11 & 3 \\
\hline Italy & 264 & 16 & 3 \\
\hline $\begin{array}{l}\text { the United } \\
\text { Kingdom }\end{array}$ & 244 & 10 & 2 \\
\hline Taiwan & 185 & 31 & 2 \\
\hline Mexico & 175 & 19 & 2 \\
\hline Spain & 153 & 14 & 2 \\
\hline Canada & 148 & 11 & 1 \\
\hline Brazil & 146 & 11 & 1 \\
\hline $\begin{array}{l}\text { Russian } \\
\text { Federation }\end{array}$ & 139 & 11 & 1 \\
\hline Turkey & 125 & 18 & 1 \\
\hline Indonesia & 115 & 22 & 1 \\
\hline Poland & 100 & 20 & 1 \\
\hline Switzerland & 93 & 18 & 1 \\
\hline Netherlands & 88 & 12 & 1 \\
\hline Source: Unite & ns Conference on Trad & Development, 2015 & \\
\hline
\end{tabular}


It can be seen from the above table that in 2015 China was the world-leading manufacturer of commodity outputs in billions of dollar reaching $\$ 2,010$, with $27 \%$ of national output and $20 \%$ of international output. This signifies that Africa can partner with China and at the same time learn how to engage in large manufacturing of finished goods from the quantum of resources it has for intra-African and international trade. Another factor that should be considered in China-Africa coupling to deal with the AFCFTA is the inflow of foreign direct investment from China to Africa or from the United States to Africa. This can be seen in figure 3.

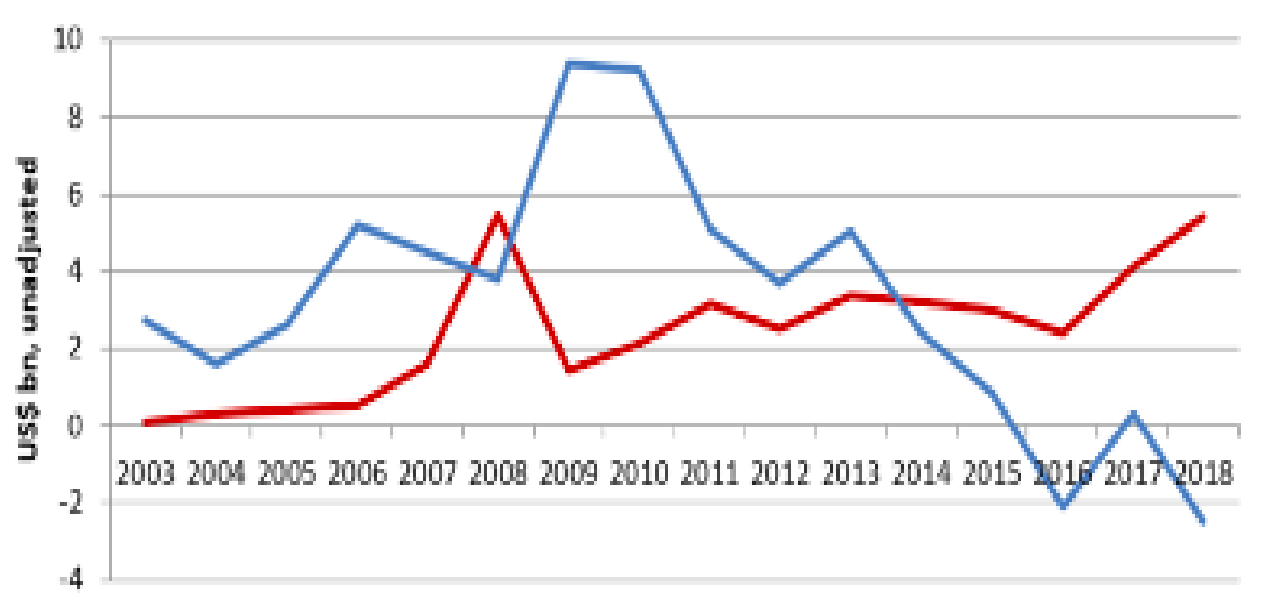

Fig.3: Flow of Chinese Vs U.S. FDI to Africa

Source: CARI. China-Africa foreign direct investment data, 2020

The above figure is based on data collected by the China Africa Research Initiative reflecting that between 2003 and 2018, the total stock of FDI from China in Africa had risen from 491 million USD to over 46 billion USD, an increase of more than 9,368 percent. At the same time, the annual outflow of FDI to Africa rose from 74 million USD to 5.4 billion USD-a 7,294 percent increase. Over the same period, the total stock of US FDI in Africa increased from 19.8 billion USD to 47.8 billion USD, and the outflow actually decreased from 2.7 billion USD to 2.5 billion USD, after a short spike following the 2008 financial crisis. In this area, China was able to successfully fill in the gap left by the United States (Amy, 2021). However, research by Catherine Boone and Dhawal Doshi found that since the late 1990s, China's FDI to Africa has been mainly directed toward extractive industries such as oil. This investment trend became known as the "Angola Model," in which China provides low-interest loans to resource-rich countries in order to secure access to those resources. Between 2004 and 2011, China's investment deals with seven of these countries reached a total value of 14 billion USD (Amy, 2021). 


\section{Figure 2:}

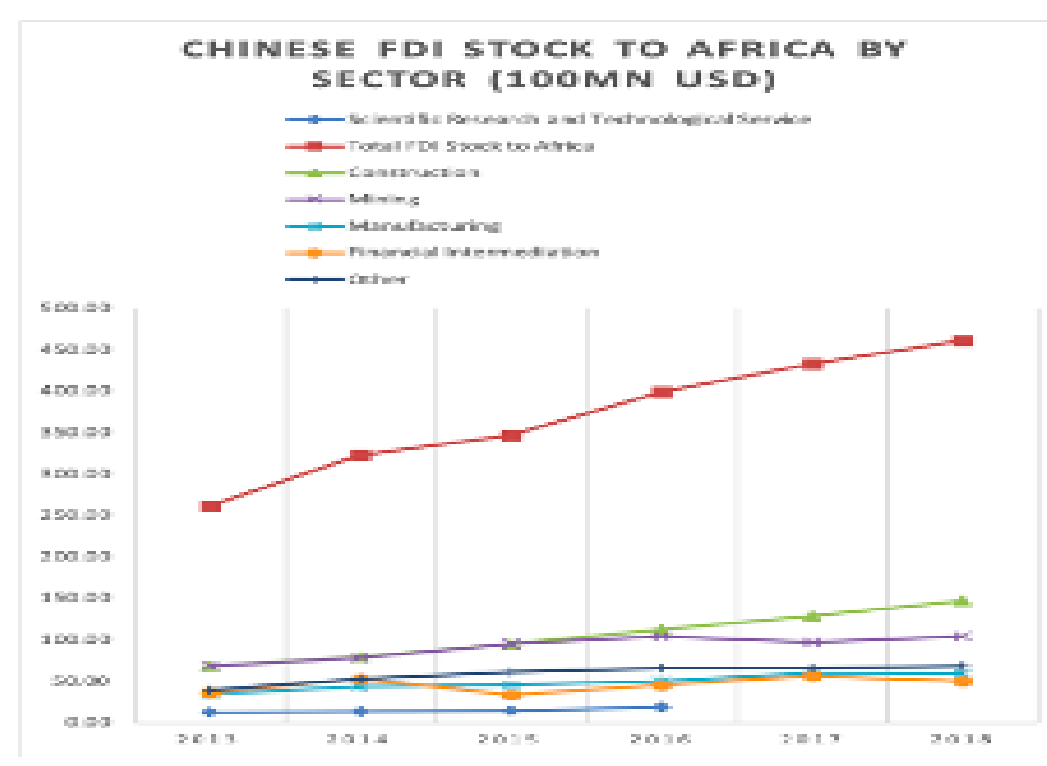

Sounce: CARI. "China-Africa Foreign
Direct Investment Data," 2020 .

Lastly, the 2013 launching of the Belt and Road Initiative (BRI) fundamentally transformed China's investment relations with Africa and the rest of the world. China opened its view to encompass more than just traditional sectors like mining and energy and adapting to modern demands, now also encompasses areas of technology and communications. Hence, the "Digital Silk Road" came about, and though still minimal compared to other sectors, investment in science, technology, innovation, and ICT has begun rising in importance in China's economic strategy in Africa (Amy, 2021).

\section{CONCLUSION AND RECOMMENDATIONS}

Looking at the nature of African relations with the United Kingdom and the United States which have not brought Africa harmony in developmental journeys, Africa should romance with the rising power, which is China in the realization of African continentalism. It is apparent that China will bring good to the African continent as the two have shared similar historical struggles and Africa can best learn from China. It is also obvious that both in the short and long run, China and African countries stand to benefit immensely in the implementation of ACFTA. In order to consolidate efforts on the strategies to achieve the goals of the new African trade arrangement, the following recommendations can be useful:

1. African countries should ratify and domesticate ACFTA and should collaborate with China for the purpose of harnessing the opportunities and surmounting the likely challenges that may emanate from the implementation process. 
2. African countries should begin to identify all potentials with which they can trade with one another and export to other continents. This may require an in-depth survey of such resources and identifying relevant companies and industries that can partner for exploration and further industrial production.

3. African countries should gradually learn from such industries and make sure that within one or two decades, the industrial technology becomes domesticated in Africa develop the ability to produce such industrial technology in African ways.

4. African countries should prioritize areas of educational learning, which have to involve science and technology, information technology, architecture and engineering, in order to create African vanguards for development.

\section{REFERENCES}

Amy, T. (2021). China's ICT Engagement in Africa: A Comparative Analysis. The Yale

Review of International Studies. Vol. 2, Winter Issue, PP. 4-18.

Corporate Finance Institute (2015). Free Trade Area. www.corporatefinance institute.com

David, D. and Aart, K. (2004). Trade, Growth and Poverty. Development Research Group. World Bank.

Ekelund, R. B. and Hébert, R. F. (1975), A History of Economic Theory and Method, New York: McGraw-Hill,

Erika, R. (2020). Free Trade Area. Investopedia. www.investopedia.com.

Franklin R. R. (2000). International Trade and Investment. Seventh edition. The Wharton

School University of Pennsylvania. South-Western Publishing Co.

George, K. (2004). What Is Free Trade? Where Is Trade Free?. New York: UN Chronicle No.

3, www.un.org/chronicle.

Hayes, A. (2021). Trade. Investopedia. www.investopedia.com.

Heckscher, E. F. (1935), Mercantilism, London: Allen \& Unwin

International Trade Centre (2018). A business guide to the African Continental Free Trade Area Agreement. ITC, Geneva.

John, B. and Steve, S. (2006). Globalization of world politics. Oxford: University Press.

Krueger, A. (1995). Free Trade Agreement versus Custom Union. Journal of International

Trade, Vol. 4, Issue 3. PP. 46-54.

Longely, R. (2018). What is Free Trade?. Definition, Theories, Pros and Cons.Thought.Co.

Lukman, R. (2020), Revenue, Welfare and Trade Effects on African Continental Free Trade

Agreement (AfCFTA) on the Nigerian economy. Distance Learning Institute,

University of Lagos, Lagos, Nigeria.

Magnusson, L. G. (2003). "Mercantilism." In Samuels, Warren J.; Biddle, Jeff E.; Davis,

John B. (eds.). A Companion to the History of Economic Thought. Blackwell

Companions to Contemporary Economics (reprint ed.), Massachusetts: Malden

Maneschi, A. (1998). Comparative Advantage in International Trade: A Historical

Perspective. Cheltenham: Elgar.

Mankiw, N. G. (2015). Economists actually agree on This: The Wisdom of Free Trade. New York Times, November.

Murschets, P. (2013). State aid for Newapapers: Theories, Cases and Action. Spinger Science +business Media. 
Onwuka, A. and Ozegbe, C. (2020), African Continental Free Trade Agreement- Does the fact supports the benefits for Nigeria? International Business Research Vol. 13 No. 7. Canadian Center of Science and Education.

O'Sullivan, A. and Sheffrin, S. M. (2003). Economics: Principles in Action. The Wall Street Journal: Classroom Edition (2nd ed.). Upper Saddle River, New Jersey: Pearson Prentice Hall: Addison Wesley Longman. p. 444. ISBN 978-0-13-063085-8.

Patience, R. (2020). An Evaluation of the African Continental Free Trade Area; Governance and Challenges. A Short Essay. The Print, July.

Sheriff, G.I., Farouk, B.I.F. and Abdulkareem, A. (2021). The Belt and Road Initiative and the Implementation of the African Continental Free Trade Area (AfCFTA) in an Emerging Regional Market. Journal of Global Economics and Business Vol. 2, No. 4, PP. 93-104.

Tenreyro, S., Liscky, M. and Koren, M. (2019). Diversification through Trade. The Quaterly Journal of Economics. Vol. 2, Issue 1. PP. 34-46.

W T O, (1994). GATT: Basic Rules for Goods. 24 September. 